\title{
Robert Boyle: Pioneer of Experimental Chemistry
}

P. A. G. O' H A R E

Few who have studied chemistry or physics, even at the most rudimentary level, have not encountered the famous relationship between the volume and pressure of a gas known as Boyle's law. Although his name presumably will live in perpetuity in connection with this law, not many scientists, even professional chemists and physicists, are aware of Boyle's other, perhaps even more significant, discoveries.

The early history of science abounds with the names of independently wealthy individuals whose circumstances and inclinations allowed them to set up and maintain laboratories of their own. Robert Boyle was such a privileged person. He was born on January 25, 1627, at Lismore Castle, County Waterford, Ireland, the last of 14 children of Richard Boyle, Earl of Cork, and Lady Catherine Fenton. Many details of his childhood and youth are given in his autobiographical An Account of Philaretus during his Minority which, Maddison ${ }^{1}$ concludes, must have been written when Boyle was about 21 years of age.

In this account, he recognized his good fortune in having been born "in a condition that neither was high enough to prove a temptation to laziness, nor low enough to discourage him from aspiring." His position, nevertheless, was a very privileged one in the Ireland of that time and afforded educational and social opportunities open to very few of his contemporary fellow countrymen. At a very tender age (perhaps as early as four), he was provided with a tutor and learned "to write a faire hand" and to speak Latin and French, in which he became very proficient. Indeed, during his later travels in

${ }^{1}$ R. E. W. Maddison, The Life of the Honourable Robert Boyle (London: Taylor and Francis, 1969), p. 2. 
Europe, he seemed to suggest that his French was better than his English! He wrote of his truthfulness and lifelong devotion to it and related an episode (reminiscent of George Washington) in which he denies having eaten half a dozen plums, but admits to having eaten "half a score."

He was about eight years of age when, along with his brother Francis, he was sent to Eton College. They arrived there in 1635, having survived storms and Turkish galleys on the Irish Sea. His willingness to learn earned him special privileges, including private tuition from the headmaster. While at Eton, he became an avid reader, being much impressed by the Historiae Alexandri Magni of Quintus Curtius Rufus. Boyle, who appears not to have enjoyed robust health throughout his life, makes reference to bouts of sickness and escape from serious injury in a collapsing room at the college, twice in falls from horses, and once from an apothecary's mistake. The latter he made reference to as "the occasion that made him afterwards so inquisitively apply himself to the study of Fisicke [i.e., medicine], that he may have the less need of them that profess it."

He spent four years at Eton. During the last year, he seems to have deserted the study of Latin for that of history. In 1639, the Earl moved his two sons to the family estate at Stalbridge in Dorset and installed them in the house of the local parson who acted as their tutor. Here Boyle's love for Latin seems to have been revived and, in his spare time, he wrote "some few verses both in French and Latin, and many copies of amorous, merry, and devout ones in English, most of which, uncommunicated, the day he came of age he sacrificed to Vulcan . . . ." He also received tuition in music, but a "bad voice soon persuaded him to desist."

His next tutor, Isaac Marcombes, a native of the Auvergne and resident of Geneva, seems to have exerted a profound influence upon the 12-year-old Robert. With him he continued his study of Latin and French and learned from Marcombes "a very cautious and considerate way of expressing himself, which after turned to his no small advantage." Four days after Francis Boyle was married to Elizabeth Killagrew in the presence of the king and queen, the bridegroom, his brother 
Robert, and Marcombes departed for France on the first part of their European tour.

The grand tour (of what are now Italy, Switzerland, Monaco, and France) certainly helped him in his mastery of languages, gave him a European outlook but, surprisingly, seems not to have had a very profound influence on his subsequent scientific career. Paris ("that vast chaos of a city"), Lyons ("fitter for the residence of merchants than of gentlemen"), Geneva (the home of Marcombes, where he spent 21 months, was taught logic, rhetoric, mathematics, and learned to play court tennis) were visited in that order. They arrived in Florence toward the end of October 1641. Here, under the tutelage of Marcombes, he studied Italian history and language and "the new paradoxes" of Galileo; it was while they were at Florence that Galileo died in nearby Arcetri. (It is interesting to note that Boyle's own portrait is now among the Gioviana Collection at the Palazzo Vecchio in Florence.)

Not all his time, apparently, was spent in study: "nor did he sometimes scruple, in his Governor's [i.e., tutor's] company to visit the famousest bordellos; whither resorting out of bare curiosity, he retained there an unblemished chastity, and still returned thence as honest as he went thither . . But though Philaretus were no fuel for forbidden flames he proved the object of unnatural ones... he was somewhat rudely pressed by the preposterous courtship of two of those friars, whose lust makes no distinction of sexes."

In Rome, he viewed the excesses of the church with a somewhat jaundiced eye. The travelers left the Eternal City because Francis was unable to tolerate the hot climate. The autobiographical account ends at Marseilles, where Philaretus saw the French king's galleys put to sea rowed by "about 2,000 poor slaves."

The Earl of Cork's sad state of affairs as a result of the Irish rebellion of 1641 ("I am deeply indebted, and have neither money, revenue, nor stock left me, nor can longer subsist for want of them") brought the grand tour to an abrupt end. Francis returned to Ireland immediately, and Robert, eventually, by way of Geneva, to England in 1644, shortly after his father's death in 1643. 


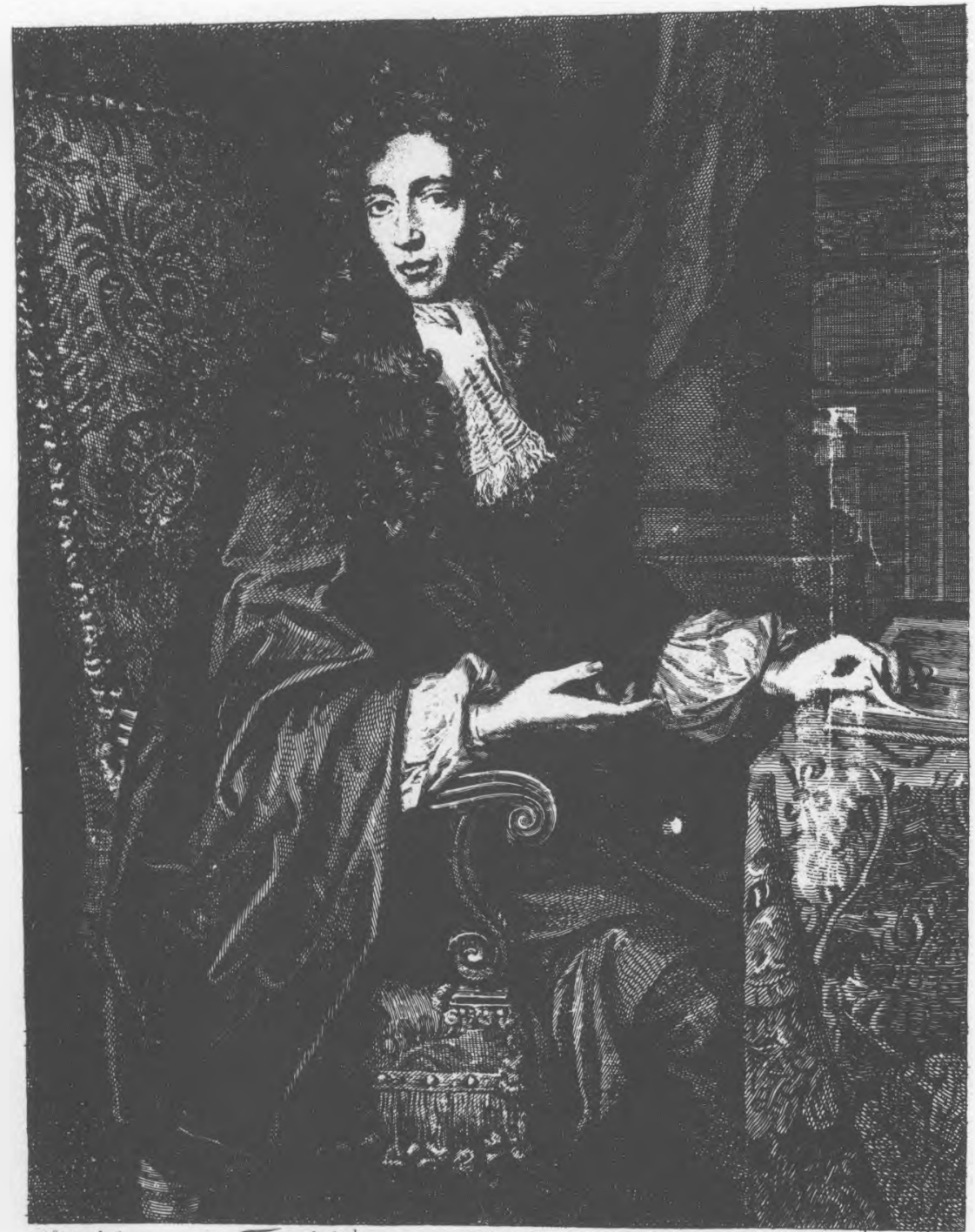

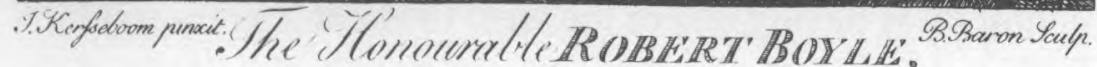


The British Isles to which Boyle returned were wracked by the Anglo-Irish wars and the English Civil War. He had intended to join the army but, fortunately, was dissuaded from doing so by his elder sister, Lady Ranelagh. She attempted to gain his support for the cause of the Parliamentarians but, as he was to do throughout his life, Boyle seems to have avoided taking a public political stance. Interestingly, his family members had rather sharply divided loyalties during the civil war; those loyalties, however, were held modestly enough so that, with the conclusion of the war, they managed to retain most of their wealth and influence.

It was during his subsequent years at Stalbridge, after forays into agriculture ("My grand employment in my spare hours," he wrote in 1646, "is to catechise my gardener and our ploughman concerning the fundamentals of their profession.") and medicine, that he began his serious chemical investigations, probably about 1649 . Boyle's early scientific thought was influenced by the writings of Francis Bacon and Galileo, whose works, we mentioned earlier, he encountered during his stay in Florence. Later, the Principles of Philosophy by Descartes became a source of inspiration. To twentieth-century experimentalists it is strange to recall that Boyle's marriage of philosophy and experimentation was frowned upon by many of the leading intellectuals of his time. The Cartesian philosophers on the continent, who knew by "pure reason" much of what Boyle was to test experimentally, looked askance upon his work. After his death, the Dutch physicist Huygens and the German mathematician Leibnitz expressed regret that Boyle had wasted his time and talents upon experimental science. Of course, many of the conclusions arrived at by "pure reason," unlike Boyle's empirical results, subsequently had to be jettisoned.

It is not easy, even for a trained chemist, to read Boyle's scientific publications. The statement has been made that he "is notorious as having one of the most tiresome literary styles on record. It is diffuse and rambling, apologetic and deprecatory, and without adequate terminal facilities." That criticism is not without merit and is at odds with Boyle's conviction that science, usually presented in mathematical forms and language, should be written about in such a way that it could be 
clearly understood by the nonscientist. In doing so, he introduced to the scientific literature a precept adopted in their publications by most modern experimental scientists, which is the description of procedures and results in sufficient detail that others, repeating or assessing the work at a later date, can do so exactly and objectively.

The decade that ended in 1655 is referred to as Boyle's Stalbridge period, during which his reputation was being established with the help of such publications as the theological treatise Seraphick Love and The Usefulness of Natural Philosophy. There are indications in Seraphick Love of his early chemical experiments on metals, and his furnaces, an essential part of his "Vulcanian feat," had now been constructed. Like many scientists of his time, he was concerned with the composition of matter. His own theory, the "corpuscular philosophy," foreshadows in certain respects modern theories of the structure of atoms and molecules. He also came to regard heat as a consequence of the motion of the particles from which matter was constructed.

Boyle belonged to a group (subsequently, the nucleus of the newly formed Royal Society) of avant-garde thinkers-mathematicians, natural philosophers, and physicians-who met regularly in London. At those gatherings, topics as diverse as Copernican astronomy, comets, and the circulation of the blood were discussed. Two of the younger members are still well remembered: Robert Hooke (whose law relates, for example, the extension of a spring to the load causing it) and Christopher Wren, the famed architect of St. Paul's Cathedral in London. With the passage of time, several members of the group took up residence in Oxford, and Boyle eventually followed them. The exact date of his move to Oxford is not known, but Maddison ${ }^{2}$ cites evidence that it probably was late in 1655 or early in 1656 .

Shortly after his arrival in Oxford, Boyle learned of a new application (in Magdeburg) of the suction pump, by means of which, it was reported, a barrel was emptied of water and, later, a metal container of air, thus creating a partial vacuum.

${ }^{2}$ Ibid., p. 89. 
With the German work as a basis and Robert Hooke as designer, Boyle and his assistants constructed the first pump expressly contrived to create a vacuum. This invention came at a time when natural philosophers were intrigued by the effects of atmospheric pressure (and theologians railed against the very idea of a vacuum!).

The Italian physicist Torricelli had demonstrated that the space above the mercury surface, formed after a tube had been filled and inverted in a bath of mercury, was devoid of air. This space is even now called the Torricellian vacuum. (For many years, the tube and bath of mercury afforded the practical method for measuring the pressure of the atmosphere.) $\mathrm{Nu}$ merous experiments had been performed in this vacuum, but the method was cumbersome at best. The new vacuum pump, itself extremely awkward by modern standards, nevertheless obviated many of the difficulties associated with Torricelli's apparatus and was described in 1660 in Boyle's first published scientific study: New Experiments Physico-Mechanical, Touching the Spring of the Air, and its Effects. The pump was employed to show the necessity of air for the transmission of sound (a ticking watch was silenced by the removal of air) and for the support of combustion (the extinction of a lighted candle in a vacuum) and of life (the death of a cat due to lack of air) - thus the "Machina Boyleana" and the "Boyleian vacuum." Further experiments in vacuo were described, including the discovery that fruits and vegetables contained what later chemists were to call "fixed air" (i.e., carbon dioxide) that was given off during fermentation. These experiments, and the embryonic Royal Society, were satirized in 1661 .

To the Danish agent late was showne

That where noe aire is ther's noe breath.

A glass this secrett did make knowne,

Wherein a catt was putt to death

Out of the glass the air being screw'd

Pus dyed and never so much as mew'd.

Although these discoveries are of profound scientific importance, it is Boyle's work on the relation of the volume to the pressure of confined air that has been historically connected with his name as "Boyle's Law." Published in 1662 as an 
appendix to the second edition of New Experiments, this hypothesis, first called a "law" by Bernoulli in 1683, states that the volume of a gas is inversely proportional to the pressure being exerted upon it, provided the temperature does not change. In other words, 1 liter of air at 1 atmosphere pressure is reduced in volume to 0.5 liter at 2 atmospheres and increased to 2 liters at 0.5 atmosphere. (Strictly, this law applies only to a "perfect" gas at very low pressures.)

To the nonhistorian of chemistry, the best known of Boyle's publications is the Sceptical Chymist which appeared in 1661. (An undergraduate pun once had it that the Septical Chemist was written by Robert Boil.) In this book, he described many of his recent experiments including the preparation of hydrogen by the action of mineral acid on steel filings and new compounds of copper and of mercury. Hall ${ }^{3}$ points out quite firmly, contrary to some opinion, that in the Sceptical Chymist Boyle did not give a modern definition of an element, but simply sought to demonstrate that what were regarded in the seventeenth century as elementary entities (e.g., fire, earth, mercury) to be found in all substances, either were not stable or simply were not found in all substances, and that the elementary building blocks of nature were fundamental particles.

For many science students, part of their introduction to analytical chemistry consists of experiments based on titrimetric (i.e., by titration) analyses. They are, in fact, following a trail opened by Robert Boyle almost 300 years ago. Some such analyses rely on color changes of added vegetable dyes brought about through the neutralization of acidic by alkaline solutions, and vice versa. Boyle was the first to study color changes caused by mixing chemicals. He found that all acids turned blue vegetable solutions red, and that those substances which were not acidic did not do so. This observation led to his classification of substances as acidic, alkaline, or neutral. The research on color changes during chemical reactions seems largely to have been performed during his Oxford period. Use of the color reagents was described for the first time in his

${ }^{3}$ Marie Boas Hall, "Boyle, Robert," Dictionary of Scientific Biography (New York: Scribner's, 1970), Vol. 2, pp. 377-82. 
Experimental History of Chemistry, published in 1665. This work was subsequently translated into Latin, thus assuring it a much larger readership, and it became familiar to many leading scientists including Isaac Newton. Descriptions of the test procedures were printed in many eighteenth-century textbooks and encyclopedias of chemistry.

Many of Boyle's most significant experimental findings were in the discipline now classified as analytical chemistry. Let us give an example or two of his discoveries in addition to the color tests: he devised methods for differentiating between gold and silver and for determining whether silver was adulterated with copper, and he used flame tests for identification purposes (certain metals when heated in a flame emit specific characteristic colors). Indeed, evidence for Boyle's introduction of the term "analytical chemistry" into the English language is cited by Burns" in a recent article. Suffice it to say that Samuel Johnson's dictionary of 1785 and the Oxford Dictionary of 1888 used Boyle's writings to explain the meaning of analysis as employed in chemistry.

It is, perhaps, appropriate that the present author, a thermodynamicist by profession, should also single out for attention the publication in 1665 of Boyle's New Experiments and Observations Touching Cold, the result of several years of study in the laboratory and of conversations and correspondence with those who had firsthand experience of extremes of cold-sea captains of the Hudson's Bay Company and Samuel Collins, physician to the czar of Russia. Boyle describes for the first time the use of an alcohol thermometer (spirit of wine colored with cochineal) for measurements of low temperatures. Such thermometers are still used in everyday laboratory work. Other significant new concepts to be found in this book include the use of freezing mixtures, cold storage for the preservation of food, and the expansion of water on freezing. Many of the experimental observations appear to have been made possible by the extremely cold winter of 1662 !

4 D. T. Burns, "Robert Boyle (1627-1691): A Foundation Stone of Analytical Chemistry in the British Isles. Part I. Life and Thought," Analytical Proceedings (London: Royal Society of Chemistry), Vol. 19 (May 1982), p. 228. 

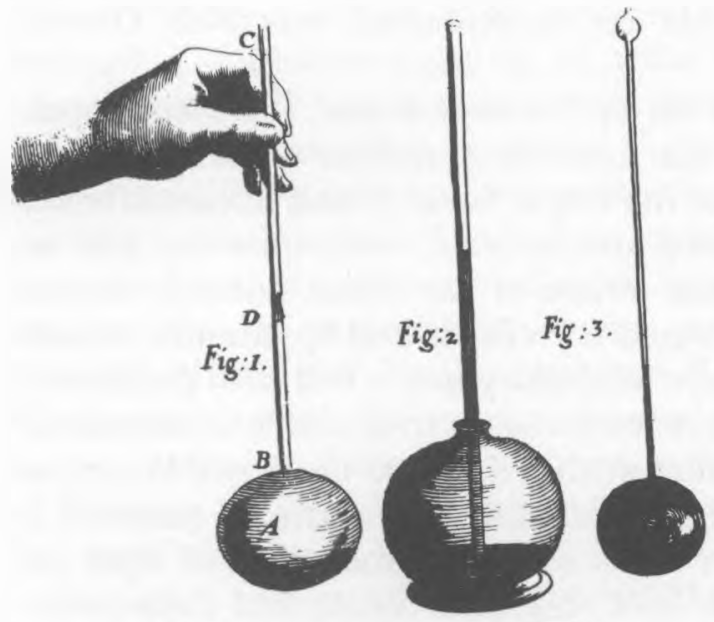

Figure 1. Page $9,10,11,2$ 98.

A the Ball or Egg.

B C the Stem.

D the little Aqueous Cylinder.

Figure 2. the open Weatherglafs mentioned pag. 24,843 .

Figure 3. the feal'd Weather-glafs or Thermofcope mentioned pag. $24,55,56$.

Figure 4. the Barometer or Mercurial Standard placed in a Frame B B mentioned pag. 25.

Figure 5. an Inftrument mentioned pag. 93.

A the Vial.

B C the Pipe cemented into the neck of the Vial, open at $C$ and feal'd at $B$.

Figure 6. pag. 97.

$A$ the Bolt-head.

$B$ the fmall Stem,

BC the Cylinder of water inclosed.

Figure 7. pag. 10r.

An illustration from Robert Boyle's New Experiments and Observations Touching Cold (London: John Crook, 1665). This book is one of 15 early works of Boyle in the University Libraries. 
In 1662, Boyle's sister, Katherine Lady Ranelagh, had moved her residence to Pall Mall in London. Subsequent correspondence between them hints at his eventual move to London, which took place in August 1668. He was to live there until his death in 1691. One of his more notorious Pall Mall neighbors, never mentioned in his correspondence, was Nell Gwyn, mistress of Charles II.

Now that Boyle had set up his new home, the voluminous correspondence with his London confreres (notably Henry Oldenburg, secretary of the Royal Society, and Robert Hooke) was no longer necessary and he was, consequently, able to devote more time to the affairs of the Royal Society. Hooke frequently visited and dined with Boyle and apparently helped with the construction of a laboratory in the Pall Mall residence. New studies of the effects of pressure (reduced and increased) were carried out. He demonstrated before the Royal Society a wide range of experiments including, for example, some on a pendulum swinging in vacuo and the production of light on mixing two liquids. In 1674, his Observations and Experiments about the Saltness of the Sea highlighted the use of distillation for the preparation of fresh water from seawater, based on his postulate that the saltiness of seawater was caused by the salt dissolved in it. In 1683, Robert Fitzgerald, a nephew of Robert Boyle, and his partners were granted a patent by the king: Engines for purifying salt and brackish water, making it sweet and fit for drinking and purposes of cooking. Maddison ${ }^{5}$ has opined that Fitzgerald's relationship to Boyle was of great advantage in procuring this patent. In that same year, Boyle was summoned before the king to demonstrate the new technique for the purification of seawater. Students of chemistry will find it interesting that Boyle demonstrated chemically the purity (i.e., absence of sodium chloride) of the distilled water by the nonappearance of a precipitate of silver chloride upon addition of a solution of silver nitrate. This analytical procedure was, in modern parlance, "classified" until after Boyle's death, although, as Maddison has pointed out, the great man himself had let the cat out of the bag as early as 1663 !

${ }^{5}$ Maddison, The Life of the Honourable Robert Boyle, p.148. 
One evening in 1677, Johann Daniel Kraft, a well-known German chemist, brought to Boyle's home for his inspection a strange new substance with unusual properties, one of which was that it glowed in the dark. Kraft was rather tight-lipped about this substance but, evidently, said enough that Boyle was able to deduce that it could be prepared from human urine. He isolated a sufficient quantity of what is now called white phosphorus to determine most of its properties that were to be known for the next 200 years: that white phosphorus could, and should, be stored under a protective covering of water to prevent oxidation; that phosphorus could exist in another, red, form; and that phosphoric acid could be produced from it. The results of those investigations were published as The Aerial Noctiluca (1680) and The Icy Noctiluca (1682). Hall' ${ }^{6}$ has stated that the latter work "deserves to be read as a classic example of early chemical analysis." In addition, a paper entitled A Method of Preparing the Phosphorus of Humane Urine was deposited with the Royal Society in 1680.

The same year in which The Acrial Noctiluca was published, Robert Boyle was elected president of the Royal Society. Surprisingly, he declined this prestigious position and wrote to Robert Hooke: "His reasons I have not now time to tell you, but they are of such a weight with me, who have a great [and perhaps peculiar] tenderness in the point of oaths, that I must humbly beg the Royal Society to proceed with a new election, and do so easy a thing, as among so many worthy persons, that compose that illustrious company, to choose a president, that may be better qualified than I for so weighty employment." His wishes were acceded to, and Sir Christopher Wren was elected in his stead.

Boyle's London period was clearly not as productive of research as his years at Stalbridge and Oxford. Boas ${ }^{7}$ has suggested that much time that could otherwise have been used for further original experimentation was wasted, inter alia, in

${ }^{6}$ Marie Boas Hall, "Robert Boyle," Scientific American, Vol. 217 (August 1967), pp. 96-102.

${ }^{7}$ Marie Boas, Robert Boyle and Seventeenth-Century Chemistry (Cambridge: Cambridge University Press, 1958), p. 207. 
chemical demonstrations for persons of influence in London society. That there would be a diminution of the marvelous stream of his publications was announced by Boyle himself in 1688. Only random accounts of various experimental findings would henceforward be published since, he said, many of his papers had been lost; furthermore, a sulfuric acid spill had destroyed others. He claimed that his notebooks had been tampered with and his writings plagiarized. His health had also begun to deteriorate. Nevertheless, as late as October 1691, Locke was helping him prepare History of the Air for publication. This work was to appear posthumously.

In July 1691, Boyle drew up his last will and testament. This document, and the various codicils, are reprinted in detail by Maddison. ${ }^{8}$ Lady Katherine died on December 23, 1691. This was a great shock to Robert Boyle who survived her by just eight days and passed away on December 31, 1691. Sir Charles Lyttleton related how, when Boyle died, "a flame broke out of one of ye chimneys, which being observed by ye neighbours gave notice of it, and, the chimney being looked into, there was no cause found for it in ye inside, yet appeared to flame for some time to those without." Shakespeare put it more poetically.

"When beggars die there are no comets seen;

The heavens themselves blaze forth the death of princes."

Robert Boyle was buried in the chancel of St. Martin-in-theFields church in London. That church was demolished just a few years afterward, in 1720, but no record had been kept of the disposal of the bodies buried there. Thus, the last resting places of Robert Boyle and his sister are unknown.

Although Boyle's reputation rests primarily on his scientific works, it is important to emphasize that he was a man of deep spiritual convictions who used his wealth and his pen to support worthy charitable and religious causes. Among those projects he supported financially and morally were translations of the Bible into Irish (An Tiomna Nuadh, 1681), Turkish (1666), and Lithuanian (ca. 1661). He left his entire wealth to "pious and other good uses," including the Boyle Lecture Sermons,

${ }^{8}$ Maddison, The Life of the Honourable Robert Boyle, p. 257. 
which are delivered to the present time. He was, from 1661, governor of the Society for the Propagation of the Gospel in New England. His religious writings, for example, The Excellency of Theology Compared with Natural Philosophy, frequently used science as a support for religion. Some of the other theological works included, among their more prominent objectives, the contention that belief in science was not synonymous with atheism and that opposition to Aristotle did not imply opposition to religion.

In all likelihood, Boyle will probably be remembered by the scientific community mostly for the law that carries his name. However, his most profound achievements appear to have been in analytical chemistry, for example, his classifications of substances as acidic, basic, or neutral; analyses of drugs supplied by apothecaries; the use of silver nitrate to detect chloride ions (as in salty water); and the introduction of colored indicators from vegetable sources. His experiments in vacuo were seminal and provided some of the first steps on the long journey that eventually led to the kinetic theory and our current understanding of the behavior of gases at extreme temperatures and pressures. His great dedication to experimental proof and meticulous reporting of his observations, both positive and negative, are still sources of inspiration. Modern editors, understandably, show little tolerance of reports of experiments that went wrong; there is simply not enough room for such in the crowded scientific literature. But Boyle felt, and rightly so, that bad experiments also can point the way to eventual success.

Nowadays, poets seldom appear to be aware of the existence of scientists (although the converse is arguably not so!) and, certainly, one would not expect a modern scientist's demise to inspire a poetic valedictory. However, it was otherwise 300 years ago, and several such were penned. The following, by Samuel Boroden, is quoted not as an example of great, or even good, poetry, but as a rather perceptive statement of Boyle's scientific philosophy:

"Then shone the learned, the industrious Boyle

And sought out Truth with an unweary'd toil; 
Boyle on Experiment alone rely'd

And Nature, which he lov'd, was still his guide."

Most of Boyle's works and correspondence are in the custody of the Royal Society (London). Two outstanding studies of his life are available in the modern literature. The most comprehensive (and readable, in my opinion) biography is by Maddison, ${ }^{9}$ while Boas ${ }^{10}$ deals with Boyle's achievements from a much more technical point of view. In a series of recently published articles, Burns ${ }^{11}$ discusses various aspects, scientific and otherwise, of Boyle's life, while two shorter articles on the same topic have been published by Hall. ${ }^{12}$

\footnotetext{
${ }^{9}$ Ibid.

10 Boas, Robert Boyle and Seventeenth-Century Chemistry.
}

11 Burns, "Robert Boyle (1627-1691): A Foundation Stone of Analytical Chemistry in the British Isles. Part I. Life and Thought," Analytical Proceedings (London: Royal Society of Chemistry), Vol. 19 (May 1982), pp. 224-33; "Robert Boyle (1627-1691): A Foundation Stone of Analytical Chemistry in the British Isles. Part II. Literary Style, Specific Contributions to the Principles and Practice of Analytical Chemical Science," Analytical Proceedings (London: Royal Society of Chemistry), Vol. 19 (June 1982), pp. 288-95; "Robert Boyle (1627-1691): A Foundation Stone of Analytical Chemistry in the British Isles. Part III. American and Dutch Connections," Analytical Proceedings (London: Royal Society of Chemistry), Vol. 22 (September 1985), pp. 253-56; "Robert Boyle (1627-1691): A Foundation Stone of Analytical Chemistry in the British Isles. Part IV. Robert Boyle's Determination of Iron in Tunbridge Water: The Earliest Quantitative Colorimetric Reaction?" Analytical Proceedings (London: Royal Society of Chemistry), Vol. 23 (March 1986), pp. 75-77; "Robert Boyle (1627-1691): A Foundation Stone of Analytical Chemistry in the British Isles. Part V. Hungarian Mines, Minerals, and Mineral Waters," Analytical Proceedings (London: Royal Society of Chemistry), Vol. 23 (October 1986), pp. 349-51.

12 Hall, Dictionary of Scientific Biography and Scientific American. 